\title{
Penetration of immunoglobulins through the Klebsiella capsule and their effect on cell-surface hydrophobicity
}

\author{
P. WILLIAMS*, P. A. LAMBERT and M. R. W. BROWN ${ }^{\dagger}$
}

\begin{abstract}
Microbiology Research Group, Department of Pharmaceutical Sciences, Aston University, Aston Triangle, Birmingham B4 7ET
\end{abstract}

\begin{abstract}
Summary. The ability of antibodies to cell-surface components of Klebsiella to increase surface hydrophobicity and to gain access to antigens potentially masked by the capsule was investigated. Treatment of capsulate or non-capsulate strains with the respective autologous antiserum resulted in a marked increase in surface hydrophobicity. Antisera raised against a rough non-capsulate $\left(\mathrm{K}^{-} \mathrm{O}^{-}\right)$strain had little effect on the surface hydrophobicity of either of the capsulate strains $\mathrm{K}^{+} \mathrm{Ol}^{+}$and $\mathrm{K}_{2}{ }^{+}$ $\mathrm{O}^{+}$, or of the non-capsulate $\mathrm{K}^{-} \mathrm{O} 1^{+}$strain. Whereas anti- $\mathrm{K}^{-} \mathrm{O} 1^{+}$sera or anti- $\mathrm{K} 2^{+}$ sera increased the surface hydrophobicity of the $\mathrm{K}^{+} \mathrm{Ol}^{+}$strain, only antisera containing anti- $\mathrm{K}^{+}$antibodies increased the hydrophobicity of the $\mathrm{K} 1^{+} \mathrm{O} 1^{+}$strain. Immunoadsorption of anti- $\mathrm{K}^{-} \mathrm{Ol}^{+}$serum by whole capsulate cells revealed that neither the $\mathrm{K} 1$ nor the $\mathrm{K} 2$ capsular polysaccharide acted as a barrier to anti-O antibodies but that the $\mathrm{K} 1$ capsular polysaccharide masked the presence of the immunoglobulin at the cell surface. The Klebsiella capsular polysaccharide does not appear to present a permeability barrier to immunoglobulins although failure to detect outer-membrane proteins in the immune complexes of either of the capsulate strains or of the $\mathrm{K}^{-} \mathrm{Ol}^{+}$strain suggests that the $\mathrm{O}$ antigen may prevent access of antibodies to these antigens.
\end{abstract}

\section{Introduction}

Phagocytic cells such as polymorphonuclear leucocytes appear to recognise foreign particles by at least two mechanisms (Stendahl, 1983; van Oss, 1978). The first is mediated via specific ligandreceptor interactions. Such ligands include the $\mathrm{Fc}$ portion of $\mathrm{IgG}$ and the $\mathrm{C} 3 \mathrm{~b}$ component of complement. However, general physico-chemical properties such as surface hydrophobicity and surface charge also play a role, and IgG and C 3 b are known to increase surface hydrophobicity of opsonised micro-organisms (Stendahl, 1983; van Oss, 1978).

Capsular polysaccharides ( $\mathrm{K}$ antigens) and the complete $\mathrm{O}$ antigen of lipopolysaccharides (LPS) confer hydrophilic characteristics upon bacterial cell surfaces. These polysaccharides are important virulence determinants (Robbins et al., 1980; Wicken and Knox, 1980). The ability of capsulate micro-organisms to resist phagocytosis in the

Received 12 April 1987; accepted 22 June 1987.

* Present Address: Department of Pharmacy, University of Nottingham, University Park, Nottingham, NG7 2RD.

† Correspondence should be sent to Prof. M. R. W. Brown. absence of specific anti-capsular antisera is well documented (Wolberg and DeWitt, 1969; Welch et al., 1979; Robbins et al., 1980; Van Dijk et al., 1981; Williams et al., 1983). However, the ability of antibodies to other cell-surface components of capsulate bacteria (e.g., LPS and outer-membrane proteins) to promote phagocytosis is less clear (Wolberg and DeWitt, 1969; Van Dijk et al., 1981; Williams et al., 1983).

Klebsiella species are important pathogens of man and are frequently isolated from hospitalacquired infections (Rennie and Duncan, 1974; Bryan et al., 1983; Cryz, 1983). Most clinical Klebsiella isolates possess a well defined capsule (Cryz, 1983) that confers serotype specificity (Kaufmann, 1949). In experimental infections, those strains expressing $\mathrm{K}$ antigen types $\mathrm{K} 1$ or $\mathrm{K} 2$ generally appear to be the most virulent (Mizuta $e t$ al., 1983; Simoons-Smit et al., 1986). Both the K and $\mathrm{O}$ antigens of Klebsiella play an important role in protecting the organism from complementmediated serum killing and phagocytosis (Williams et al., 1983, 1986; Simoons-Smit et al., 1986). In some strains, anti-O antibodies as well as anti-K antibodies can opsonise the organism, whereas 
antisera to other outer-membrane (OM) components have little effect on phagocytosis (Williams et al., 1983). Loss of the $\mathrm{K}$ antigen by mutation renders an organism (now $\mathrm{K}^{-} \mathrm{O}^{+}$) susceptible to phagocytosis following opsonisation by complement in the absence of specific antisera (Williams et al., 1983, 1986; Simoons-Smit et al., 1986). Opsonisation of $\mathrm{a} \mathrm{K}^{-} \mathrm{O}^{+}$strain by complement alone markedly increases its surface hydrophobicity (Williams et al., 1986). In the present study, we investigated the effect of antisera to specific cellenvelope components on surface hydrophobicity. We also studied the role of the capsule as a barrier to the penetration of antibodies to cell-envelope components masked by the exopolysaccharide matrix.

\section{Materials and methods}

\section{Bacterial strains}

Klebsiella aerogenes (also called $K$. pneumoniae) strain $5055(\mathrm{~K} 2, \mathrm{O} 1)$ was obtained from the National Collection of Type Cultures, Central Public Health Laboratory, Colindale Avenue, London NW9 5HT. Mutants M10 $\left(\mathrm{K}^{-} \mathrm{Ol}^{+}\right)$and $\mathrm{M} 10 \mathrm{~B}\left(\mathrm{~K}^{-} \mathrm{O}^{-}\right)$, both derived from strain 5055 , were kindly donated by Drs I. R. Poxton and I. W. Sutherland. Strain DL1 $\left(\mathrm{K}^{+}{ }^{+} \mathrm{Ol}^{+}\right)$was a clinical isolate (Williams et al., 1983). Bacteria were grown for $18 \mathrm{~h}$ on Nutrient Agar (Lab M, Ford Lane, Salford, M6 6PB) at $37^{\circ} \mathrm{C}$ and resuspended in the appropriate buffer (see below). Growth on solid media reduces the loss of capsular material associated with growth in shaking incubators.

\section{Preparation of antisera}

Antisera to whole formalin-treated cells were raised in New Zealand White rabbits as described before (Williams et al., 1983). Absorption of antiserum raised against the $\mathrm{K} 2 \mathrm{O} 1$ strain with whole $\mathrm{M} 10\left(\mathrm{~K}^{-} \mathrm{O} 1^{+}\right)$cells was also performed as previously described (Williams et al., 1983). All antisera were heat-inactivated $\left(30 \mathrm{~min}\right.$ at $\left.56^{\circ} \mathrm{C}\right)$ before use, because complement alone increases the surface hydrophobicity of the non-capsulate Klebsiella strains (Williams et al., 1986).

\section{Opsonisation of bacteria}

To investigate the influence of specific antisera on cellsurface hydrophobicity and the ability of immunoglobulins to penetrate through the Klebsiella capsule, bacteria were resuspended in $10 \mathrm{~mm}$ phosphate-buffered saline $p \mathrm{H} 7.2$ (PBS) to an absorbance at $470 \mathrm{~nm}\left(\mathrm{E}_{470}\right)$ of 1.0 and incubated for $30 \mathrm{~min}$ at $37^{\circ} \mathrm{C}$ with $1.0 \mathrm{ml}$ of the appropriate heat-inactivated antiserum or heat-inactivated non-immune rabbit serum. Bacteria were harvested by centrifugation and washed twice in PBS before use in hydrophobicity or immunoadsorption assays.

\section{Cell-surface hydrophobicity}

Surface hydrophobicity of opsonised and non-opsonised bacterial cells was determined by the two-phase partition method described by Rosenberg (1984), as modified by Williams et al. (1986); octane was used as the hydrocarbon phase.

\section{Isolation of outer membranes and LPS}

Outer membranes were prepared by a modification of the method of Filip et al. (1973) with sodium N-lauryl sarcosinate (Sarkosyl) 2\% w/v, as described by Williams et al. (1984). LPS was extracted by digestion of OMs with proteinase $\mathrm{K}$ (Sigma) according to the method of Hitchcock and Brown (1983). After digestion, the preparation was incubated in sodium dodecyl sulphatepolyacrylamide gel electrophoresis (SDS-PAGE) denaturing buffer for $10 \mathrm{~min}$ before electrophoresis.

\section{Electrophoresis and immunoblotting}

Outer membranes, LPS and antigen-antibody complexes were subjected to SDS-PAGE by the method of Lugtenberg et al. (1975). For separation of LPS, 4M urea was added to the gels. After separation by SDS-PAGE, the antigens were transferred to nitrocellulose paper in a Bio-Rad Transblot Cell as described by Towbin et al. (1979). After transfer, antigens were detected by the method of Jessop and Lambert (1985), modified by the use of staphylococcal protein A-horse radish peroxidase conjugate (Sigma) diluted 1 in 2000 for visualisation of the immunoreactive components.

\section{Permeability of the Klebsiella capsule to immunoglobulins}

The permeability of the Klebsiella capsule to immunoglobulins was investigated by a modification of the method of Swanson (1981) as adapted by Jessop and Lambert (1985). Briefly, cells were treated with antiserum to $K$. aerogenes strain $\mathrm{M} 10\left(\mathrm{~K}^{-} \mathrm{O}^{+}\right)$, or with $\mathrm{PBS}$ for controls, as described above. Bacterial cells were resuspended in $10 \mathrm{ml}$ of Empigen $2 \% \mathrm{w} / \mathrm{v}$ and shaken for $90 \mathrm{~min}$ at $37^{\circ} \mathrm{C}$ to lyse the cells without dissociating antigen-antibody complexes. Unlysed cells were removed by centrifugation and the supernate passed through a $0.5 \mathrm{ml}$ bed volume of protein A-Sepharose CL4B (Pharmacia) packed in a Pasteur pipette. The column was eluted with Empigen $2 \%$ w/v to remove material remaining within the Sepharose gel but not bound to protein A via IgG. The protein A-Sepharose column containing the bound antigen-antibody complexes was then washed three times in 10-ml volumes of distilled water and then resuspended in $0.5 \mathrm{ml}$ of ethanol for storage overnight at $-20^{\circ} \mathrm{C}$. The ethanol was removed by aspiration and the 
Sepharose was suspended in $0.5 \mathrm{ml}$ of water. After incubation in SDS-PAGE denaturing buffer at $100^{\circ} \mathrm{C}$ for $10 \mathrm{~min}$ the Sepharose was subjected to SDS-PAGE and immunoblotting. Immunoblots were developed with anti $\operatorname{M10}\left(\mathrm{K}^{-} \mathrm{Ol}^{+}\right)$serum. By use of this method, the visualisation of heavy and light immunoglobulin chains on the immunoblots was avoided. As a further control, antiserum was passed over the protein A-sepharose column. SDS-PAGE of the resulting immune-complexes revealed the presence of immunoglobulin heavy and light chains on the immunoblots only by amido black staining; they were not visualised by immunodetection (data not shown).

\section{Results}

Influence of specific antisera on cell-surface hydrophobicity

Treatment of either capsulate or non-capsulate Klebsiella strains with heat-inactivated non-immune rabbit serum had little effect on cell-surface hydrophobicity (fig. 1A). $\mathrm{K}^{+} \mathrm{Ol}^{+}, \mathrm{K}^{+}{ }^{+} 1^{+}$and $\mathrm{K}^{-} \mathrm{Ol}^{+}$strains are all hydrophilic and failed to partition into the hydrocarbon layer. With the $\mathrm{K}^{-}$ $\mathrm{O}^{-}$strain, there was a small but significant increase in hydrophobicity compared with the $\mathrm{K}^{+} \mathrm{Ol}^{+}$, $\mathrm{K}_{2}^{+} \mathrm{Ol}^{+}$and $\mathrm{K}^{-} \mathrm{Ol}^{+}$strains in the presence (fig. 1A) or absence (Williams et al., 1986) of non- immune heat-inactivated serum. In contrast, exposure of the capsulate and non-capsulate strains to the corresponding autologous antisera resulted in marked increases in hydrophobicity of all strains (fig. 1B). Therefore sera containing anti-capsular antibodies profoundly affect the cell-surface hydrophobicity of the capsulate strains. Treatment of the $\mathrm{K}_{2}{ }^{+} \mathrm{O} 1^{+}$and $\mathrm{K}^{+}{ }^{+} \mathrm{O}^{+}$strains with anti-M10 (anti$\mathrm{K}^{-} \mathrm{Ol}^{+}$) serum increased the surface hydrophobicity of the Klebsiella strain expressing the type 2 capsular polysaccharide but had no effect upon strain DLl $\left(\mathrm{K}^{+} \mathrm{Ol}^{+}\right)$(fig. $\left.2 \mathrm{~A}\right)$. Absorption of the anti- $\mathrm{K}_{2}{ }^{+} \mathrm{Ol}^{+}$serum with whole $\mathrm{K}^{-} \mathrm{O} 1^{+}$cells to remove all antibodies except the anti-K 2 antibodies confirmed that either anti-capsular antibodies alone or antibodies to other OM components increased the cell-surface hydrophobicity of $K$. aerogenes NCTC $5055\left(\mathrm{~K} 2^{+} \mathrm{Ol}^{+}\right)$(fig. 2A). Exposure of this strain to antiserum raised against the $\mathrm{K}^{-} \mathrm{O}^{-}$strain had no effect on cell-surface hydrophobicity (fig. 2B) which suggests that the anti-O antigen component of the anti- $\mathrm{K}^{-} \mathrm{Ol}^{+}$serum was responsible for increasing the cell-surface hydrophobicity of the $\mathrm{K}^{+}{ }^{+} \mathrm{O}^{+}$Klebsiella strain. Fig. $2 \mathrm{~B}$ also shows that anti- $\mathrm{K}^{-} \mathrm{O}^{-}$serum had little effect on the cellsurface hydrophobicity of either $\mathrm{K}^{+} \mathrm{Ol}^{+}$or $\mathrm{K}^{-}$ $\mathrm{Ol}^{+}$strains.
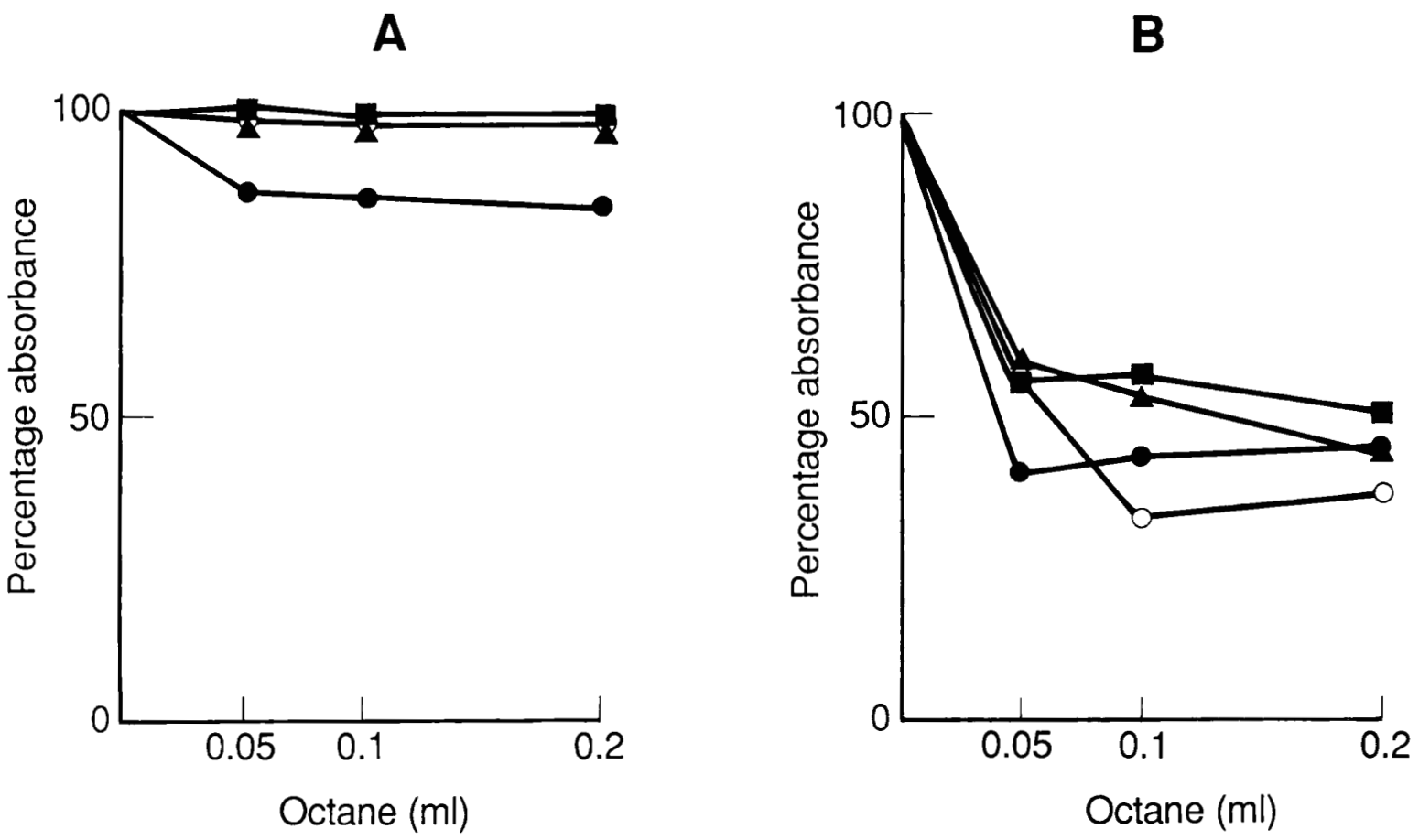

Fig. 1. Effect of antibodies on cell-surface hydrophobicity measured by adherence to octane: $\mathbf{A}$, heat-inactivated non-immune serum on $\mathrm{K}^{+} \mathrm{Ol}^{+}(\boldsymbol{\square}), \mathrm{K}^{+} \mathrm{Ol}^{+}(\mathrm{O}), \mathrm{K}^{-} \mathrm{Ol}^{+}(\mathbf{A})$ and $\mathrm{K}^{-} \mathrm{O}^{-}(\mathbf{O})$ strains; $\mathbf{B}$, heat-inactivated autologous antiserum on each of the four strains. 
$\mathbf{A}$

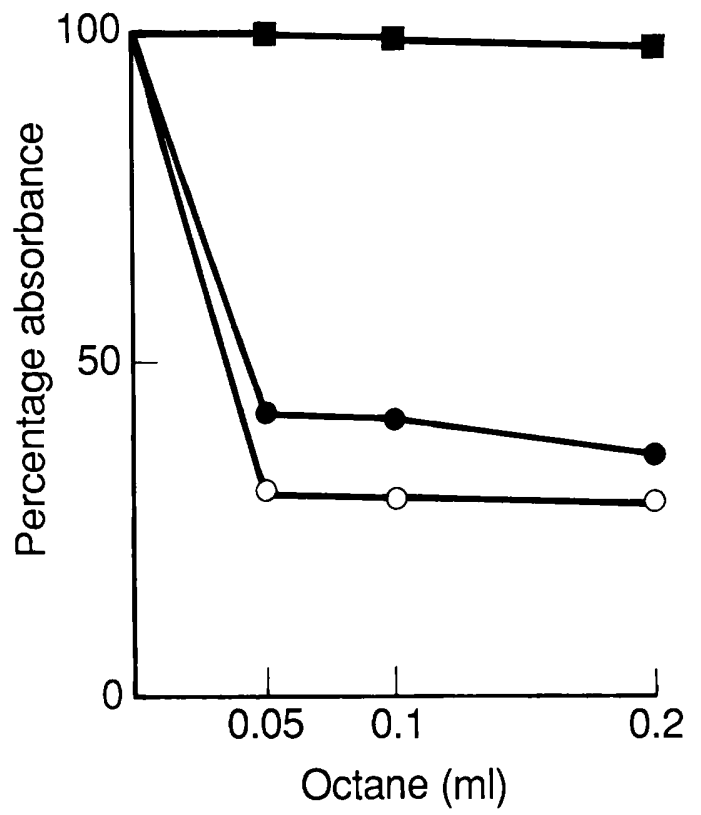

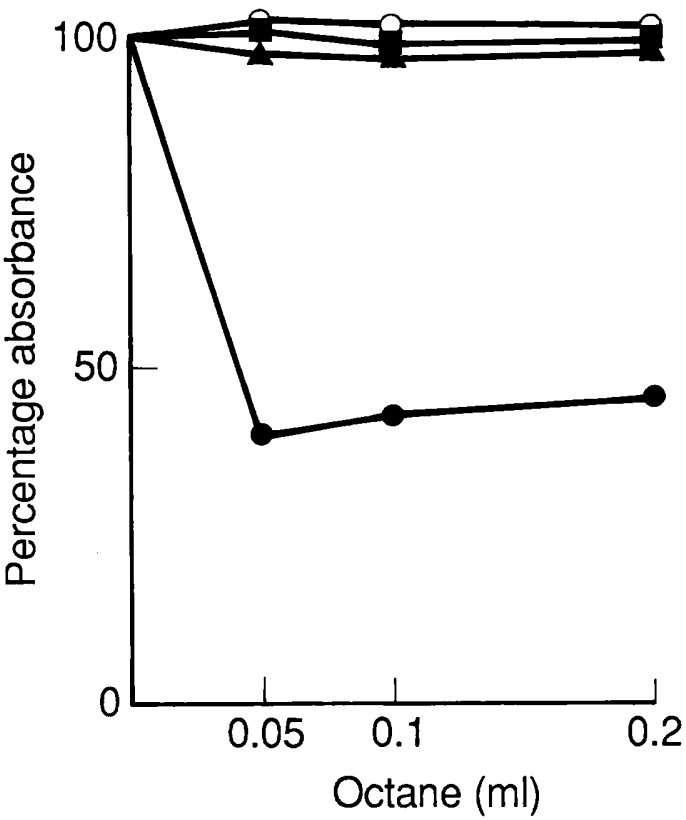

Fig. 2. Effect of antibodies on cell-surface hydrophobicity measured by adherence to octane: $\mathbf{A}$, anti- $\mathrm{K}^{-} \mathrm{Ol}^{+}$serum $^{+} \mathrm{Kl}^{+} \mathrm{O} 1^{+}$

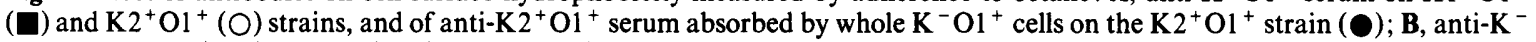
$\mathrm{O}^{-}$serum on $\mathrm{K}^{+} \mathrm{Ol}^{+}(\square), \mathrm{K}^{+} \mathrm{Ol}^{+}(\mathrm{O}), \mathrm{K}^{-} \mathrm{Ol}^{+}(\mathbf{\Delta})$ and $\mathrm{K}^{-} \mathrm{O}^{-}(\mathbf{O})$ strains.

\section{Penetration of immunoglobulins through the Klebsiella capsule}

Surface hydrophobicity experiments revealed that antibodies to the $\mathrm{O} 1$ antigen of LPS could alter the surface properties of one capsulate Klebsiella strain possessing the type 2 capsular polysaccharide but not of a strain sharing the same $\mathrm{Ol}$ antigen but with a type 1 capsular polysaccharide. To investigate whether the $\mathrm{K} 1$ capsular polysaccharide presented a barrier to these anti-O1 antibodies, a procedure was devised in which immunoadsorption of anti- $\mathrm{K}^{-} \mathrm{Ol}^{+}$antiserum by whole cells $\left(\mathrm{K}^{+} \mathrm{Ol}^{+}\right.$, $\mathrm{K}^{+} \mathrm{Ol}^{+}$and $\mathrm{K}^{-} \mathrm{Ol}^{+}$) was followed by recovery and analysis of the immune complexes. In fig. 3 the OM protein profiles (A) of the three strains and immunoblots (B and $\mathrm{C}$ ) developed with antiserum raised against the $\mathrm{K}^{-} \mathrm{Ol}^{+}$strain are compared. The immunoblots clearly show that this antiserum contained antibodies to the OM proteins (B) and to the LPS (C). Immunoblots of the immune complexes recovered after immunoadsorption of the anti- $\mathrm{K}^{-} \mathrm{Ol}^{+}$serum by capsulate or non-capsulate Klebsiella strains are shown in fig. 4. The major antigenic component of the immune complexes was
LPS. However, because this immunoblot was obtained from an SDS-polyacrylamide gel run without urea so that the presence of OM proteins would be clearly apparent, the LPS from these Klebsiella strains has run predominantly as a smear. Therefore the presence of LPS as the major antigenic component of the immune complexes reveals that the capsular polysaccharides do not form a barrier to the penetration of anti-O antibodies. Comparison of lanes 1,2 and 3 in fig. 4 with an immunoblot of the $\mathrm{OM}$ of the $\mathrm{K}_{2}{ }^{+} \mathrm{Ol}^{+}$strain (lane 4) also shows that, even in the non-capsulate strain, the OM proteins appear to be poorly accessible to antibodies. This suggests that the $\mathrm{O}$ antigen may act as a barrier to their penetration.

\section{Discussion}

Autologous heat-inactivated antiserum exerted a profound effect on the cell-surface hydrophobicity of capsulate and non-capsulate Klebsiella strains. These increases in surface hydrophobicity, which should favour phagocytic recognition, correlate well with the pattern of susceptibility to phago- 

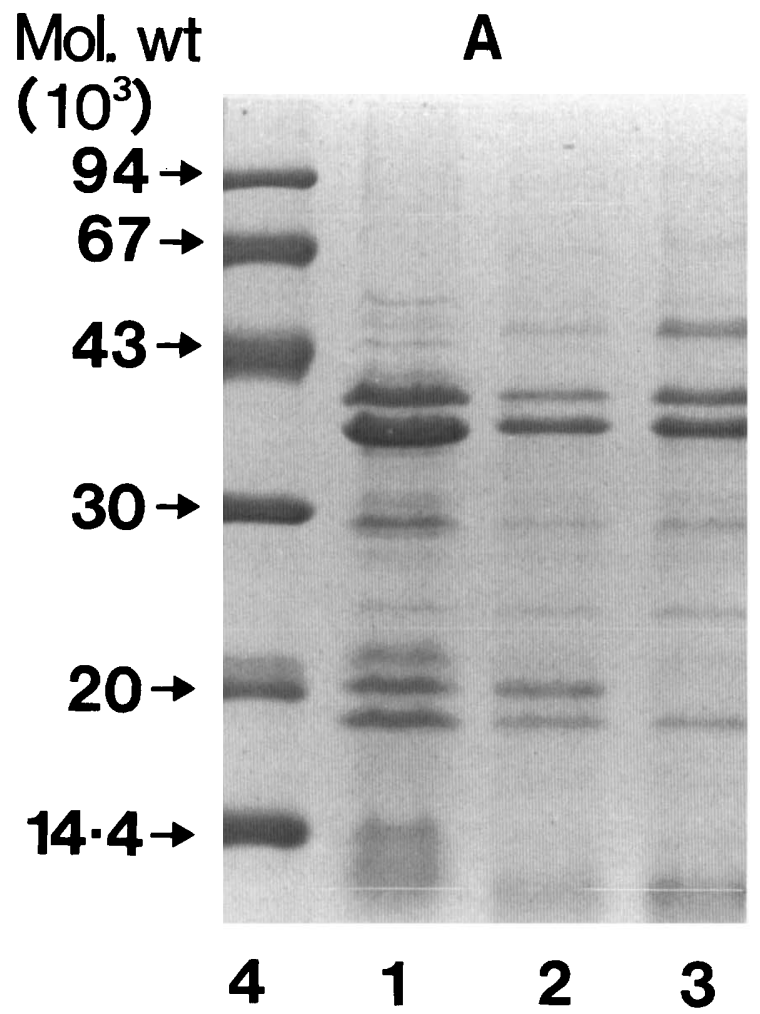
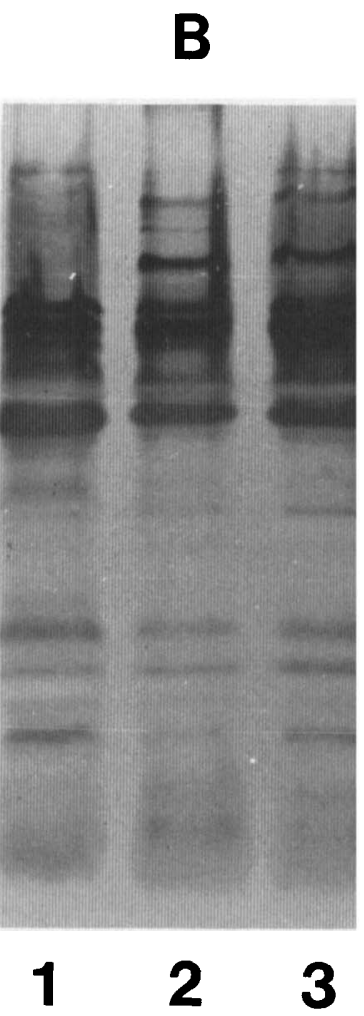

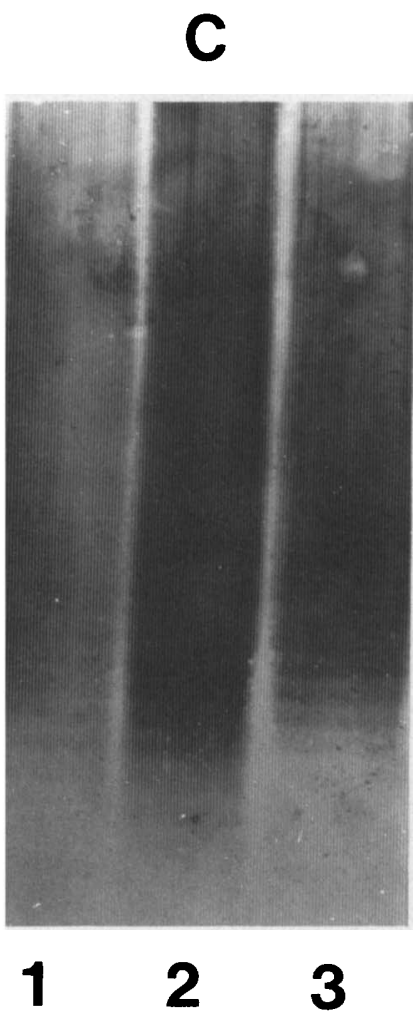

Fig. 3. A, SDS-PAGE of the OM proteins of Klebsiella strains $\mathrm{K}^{+} \mathrm{Ol}^{+}$(lane 1), $\mathrm{K}^{+} \mathrm{Ol}^{+}$(lane 2) and $\mathrm{K}^{-} \mathrm{O} 1^{+}$(lane 3 ); lane 4 shows mol. wt $\left(10^{3}\right)$ marker proteins. B and $\mathbf{C}$, immunoblots of the OM proteins (B) and the LPSs (C) of the strains shown in A developed with antiserum raised against the $\mathrm{K}^{-} \mathrm{O}^{+}$strain. A and $\mathrm{B}$ were run on $15 \%$ polyacrylamide gels. To enhance $\mathrm{LPS}$ ladder patterns, the immunoblot in $\mathrm{C}$ was obtained from a $10 \%$ polyacrylamide gel containing $4 \mathrm{M}$ urea.

cytosis in the presence of specific antisera previously reported (Williams et al., 1983). Such opsonising antibodies must, therefore, enhance the specific ligand-receptor interaction as well as rendering the bacterial surface more liable to hydrophobic interaction.

Antiserum to the $\mathrm{O}$ antigen as well as to the $\mathrm{K}$ antigen have been found to increase surface hydrophobicity and promote phagocytosis (Williams et al., 1983) of the $\mathrm{K} 2^{+} \mathrm{O} 1{ }^{+}$Klebsiella strain. The portion of the immunoglobulin molecule responsible for increasing surface hydrophobicity is the Fc fragment (van Oss, 1978; Stendahl, 1983). This fragment must, therefore, be exposed outside the capsule and on the bacterial surface. However, anti-O1 antiserum failed to increase cell-surface hydrophobicity or promote phagocytosis (Williams et al., 1983) of a strain possessing the same $\mathrm{O} 1$ antigen but with a $\mathrm{K} 1$ capsular serotype. This $\mathrm{K}$ antigen must either mask, or prevent access of antibodies to, the $\mathrm{O}$ antigen. Immunoadsorption of the anti- $\mathrm{K}^{-} \mathrm{O}^{+}$serum by whole cells revealed that both $\mathrm{K} 1$ and $\mathrm{K} 2$ capsules were permeable to anti-
$\mathrm{O}$ antibodies, indicating that, in the $\mathrm{K} 1$ serotype, anti-O antibodies were bound but not exposed at the cell surface. Therefore, surface hydrophobicity and phagocytosis (Williams et al., 1983) were not enhanced.

By exploiting the presence of protein $\mathrm{A}$ in the cell wall, King and Wilkinson (1981) showed that the capsule of Staphylococcus aureus did not act as a diffusion or permeability barrier to IgG. They suggested that the resistance of capsulate staphylococci to phagocytosis was the result of masking of immunoglobulins and complement components bound to the cell wall. In gram-negative bacteria, several investigators have reported that only anti$K$ antibodies were opsonic and protective in experimental animal infections (Welch et al., 1979; van Dijk et al., 1981). Anti-KO but not anti-O serum alone enhanced clearance of capsulate Escherichia coli injected intravenously (Howard and Glynn, 1971). However, others have shown that antibodies to somatic antigens react with capsulate $E$. coli and can promote binding of complement to the bacterial cell surface (Horwitz and Silverstein, 


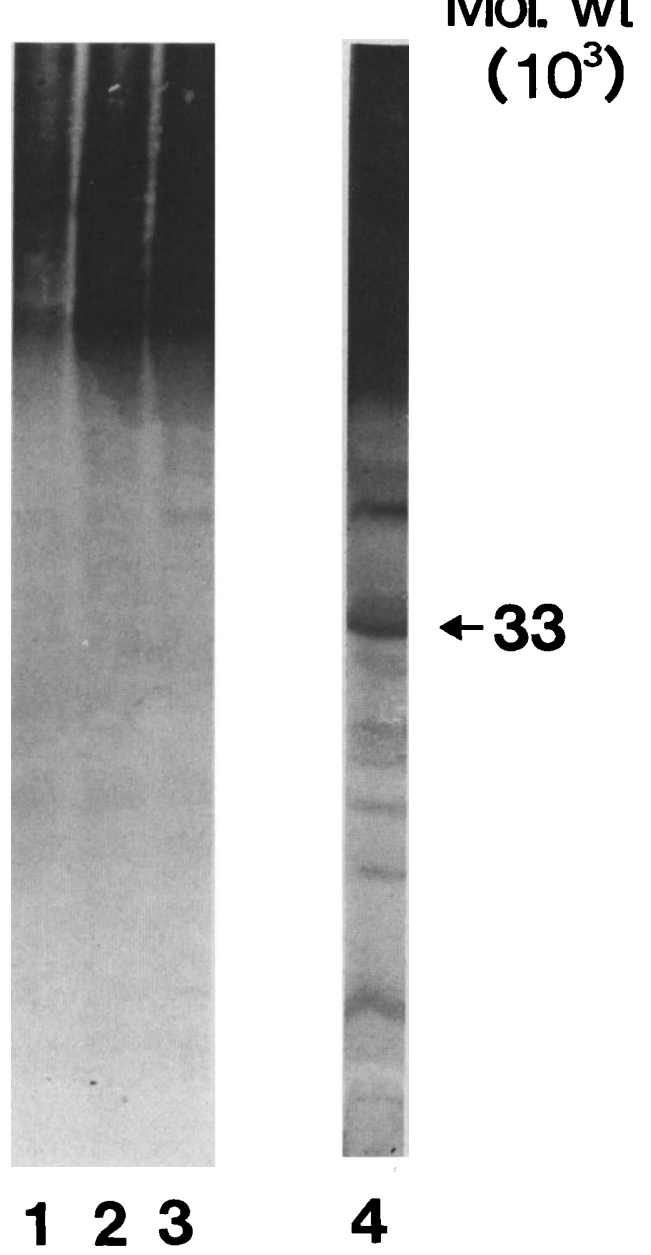

Fig. 4. Immunoblot of the immune complexes obtained after immunoadsorption of anti- $\mathrm{K}^{-} \mathrm{Ol}^{+}$serum by whole cells of the $\mathrm{K}^{+}{ }^{+} 1^{+}$(lane 1 ), $\mathrm{K}_{2}{ }^{+} \mathrm{O}^{+}$(lane 2 ) and $\mathrm{K}^{-} \mathrm{O} 1^{+}$(lane 3) strains. Lane 4 is an immunoblot of the $\mathrm{OM}$ proteins of the $\mathrm{K}^{+} \mathrm{Ol}^{+}$ strain also developed with anti $\mathrm{K}^{-} \mathrm{Ol}^{+}$serum. These immunoblots were obtained from 15\% polyacrylamide gels. (Immunoblots of controls with whole cells absorbed with buffer instead of antiserum showed no immunoreactive components.)

1980) and protect experimental animals against lethal infections (Kaijser et al., 1972).

In Klebsiella, we have shown that the $\mathrm{K}$ antigen does not prevent access of anti-O antibodies but may mask their presence. Further investigation is required to determine whether the size of the capsule, the specific $\mathrm{K}$ antigen, or both, are important. Several investigators have explored the relationship between capsular size and pathogenicity in Klebsiella (Ehrenworth and Baer, 1956;
Domenico et al., 1982; Cryz et al., 1984). Colonial variants of Klebsiella possessing small capsules were reported to be much less virulent than the parent strains in burn-traumatised mice (Cryz et al., 1984) and in a rat lobar pneumonia model (Domenico et al., 1982). We have also shown that physical reduction in the amount of capsule promoted phagocytosis of the $\mathrm{KI}^{+} \mathrm{O}^{+}$Klebsiella strain after opsonisation with anti-O1 sera (Williams et al., 1983). Thus, although the capsule does not present a permeability barrier, its size appears to determine whether antibodies to somatic antigens are exposed on the cell surface and are accessible to phagocytic cells.

The failure of antibodies to gain access to OM proteins in both capsulate and non-capsulate strains indicates that the $\mathrm{O}$ antigen acts as a barrier to their penetration. In this respect, Klebsiella resembles Serratia marcescens, with which immunoadsorption of antiserum with whole cells revealed that only the $\mathrm{O}$ antigen chains of LPS and the flagellar (H) antigen were accessible to antibodies (Jessop and Lambert, 1985). Furthermore, van der Ley et al. (1986) reported that the presence of a complete $\mathrm{O}$ antigenic side chain prevented access of antibodies to the OM pore protein Pho E at the surface of intact enterobacteria.

The growth environment, including the presence of antibiotics, exerts a profound effect on bacterial cell-envelope components in general (Brown and Williams, 1985), including bacterial exopolysaccharides (Sutherland, 1977). The nutritional conditions in vivo during infections may not only influence capsule size but also the size of the pores and channels within the exopolysaccharide matrix. Growth in the presence of sub-inhibitory concentrations of antibiotics, including cephalosporins (Kadurugamuwa et al., 1985a; Williams, 1987) and ciprofloxacin (Williams, 1987) influenced the Klebsiella capsule such that a greater number of protein antigenic sites became exposed at the cell surface and accessible to antibodies (Kadurugamuwa et al., 1985b) and complement (Williams, 1987). Further work is required, therefore, to determine whether growth conditions can influence penetration of antibodies to subcapsular envelope components and the subsequent opsonisation and phagocytosis of capsulate Klebsiellae.

We thank the Medical Research Council and Cystic Fibrosis Research Trust for generous support. 


\section{REFERENCES}

Brown M R W, Williams P 1985 The influence of environment on envelope properties affecting survival of bacteria in infections. Annual Reviews in Microbiology 39:527-556.

Bryan C S, Reynolds K L, Brenner E R 1983 Analysis of 1,186 episodes of gram-negative bacteremia in non-university hospitals: the effects of antimicrobial chemotherapy. Reviews of Infectious Diseases 5:629-638.

Cryz S J 1983 Progress in immunization against Klebsiella infections. European Journal of Clinical Microbiology 6: 523 528.

Cryz S J, Furer E, Germanier R 1984 Experimental Klebsiella pneumoniae burn wound sepsis: role of capsular polysaccharide. Infection and Immunity 43:440-441.

Domenico P, Johanson W G, Straus D C 1982 Lobar pneumonia in rats produced by clinical isolates of Klebsiella pneumoniae. Infection and Immunity 37:327-335.

Ehrenworth L, Baer H 1956 The pathogenicity of Klebsiella pneumoniae for mice: relationship to the quantity and rate of production of type-specific capsular polysaccharide. Journal of Bacteriology 72:713-717.

Filip C, Fletcher G, Wulff J L, Earhart C F 1973 Solubilization of the cytoplasmic membrane of Escherichia coli by the ionic detergent sodium-lauryl sarcosinate. Journal of Bacteriology $115: 717-722$.

Hitchcock P J, Brown T M 1983 Morphological heterogeneity among Salmonella lipopolysaccharide chemotypes in silverstained polyacrylamide gels. Journal of Bacteriology 154:269-277.

Horwitz M A, Silverstein S C 1980 Influence of the Escherichia coli capsule on complement fixation and on phagocytosis and killing by human phagocytes. Journal of Clinical Investigation 65 : $82-94$.

Howard C J, Glynn A A 1971 The virulence for mice of strains of Escherichia coli related to the effects of $\mathrm{K}$ antigens on their resistance to phagocytosis and killing by complement. Immunology 20:767-777.

Jessop H L, Lambert P A 1985 Immunochemical characterization of the outer membrane complex of Serratia marcescens and identification of antigens accessible to antibodies on the cell surface. Journal of General Microbiology 131 : 2343 2348 .

Kadurugamuwa J L, Anwar H, Brown M R W, Zak O 1985a Effect of sub-inhibitory concentrations of cephalosporins on surface properties and siderophore production in irondepleted Klebsiella pneumoniae. Antimicrobial Agents and Chemotherapy 27: 220-223.

Kadurugamuwa J L, Anwar H, Brown M R W, Zak O $1985 b$ Protein antigens of encapsulated Klebsiella pneumoniae surface exposed after growth in the presence of subinhibitory concentrations of cephalosporins. Antimicrobial Agents and Chemotherapy 28: 195-199.

Kaijser B, Holmgren J, Hanson L A 1972 The protective effect against $E$. coli of $\mathrm{O}$ and $\mathrm{K}$ antibodies of different immunoglobulin classes. Scandinavian Journal of Immunology $1: 27-32$

Kaufmann F 1949 On the serology of the Klebsiella group. Acta Pathologica et Microbiologica Scandinavica 26:381-406.

King B F, Wilkinson B J 1981 Binding of human immunoglobulin G to protein A in encapsulated Staphylococcus aureus. Infection and Immunity 33:666-672.

Lugtenberg B, Meijers J, Peters R, van der Hoek P, van Alphen L 1975 Electrophoretic resolution of the major outer membrane protein of $E$. coli $\mathrm{K} 12$ into 4 bands. FEBS Letters 58: $254-258$

Mizuta K, Ohta M, Mori M, Hasegawa T, Nakashima I, Kato
N 1983 Virulence for mice of Klebsiella strains belonging to the $\mathrm{Ol}$ group: relationship to their capsular (K) types. Infection and Immunity 40:56-61.

Rennie R P, Duncan I B R 1974 Combined biochemical and serological typing of clinical isolates of Klebsiella. Applied Microbiology 28: 534-539.

Robbins J B, Schneerson R, Egan W B, Vann W, Liu D T 1980 Virulence properties of bacterial capsular polysaccharides-unanswered questions. In: Smith $\mathrm{H}$ et al. (eds) The molecular basis of microbial pathogenicity. Verlag Chemie, Weinheim, pp 115-132.

Rosenberg M 1984 Bacterial adherence to hydrocarbons: a useful technique for studying cell surface hydrophobicity. FEMS Microbiology Letters 22: 289-295.

Simoons-Smit A M, Verweij-van Vught A M J J, Maclaren D M 1986 The role of $\mathrm{K}$ antigens as virulence factors in Klebsiella. Journal of Medical Microbiology 21 : 133-137.

Stendahl O 1983 The physicochemical basis of surface interaction between bacteria and phagocytic cells. In: Easmon C S F et al. (eds) Medical microbiology vol 3. Role of the envelope in the survival of bacteria in injections. Academic Press, London pp 137-152.

Sutherland I W (ed) 1977 Surface carbohydrates of the prokaryotic cell. Academic Press, London.

Swanson J 1981 Surface-exposed protein antigens of the gonococcal outer membrane. Infection and Immunity 34:804-816

Towbin H, Staehelin T, Gordon J 1979 Electrophoretic transfer of proteins from polyacrylamide gels to nitrocellulose sheets. Procedure and some applications. Proceedings of the National Academy of Sciences of the USA 76:4350-4354.

Van der Ley P, Kuipers O, Tommassen J, Lugtenberg B 1986 O antigenic chains of lipopolysaccharide prevent binding of antibody molecules to an outer membrane pore protein in Enterobacteriaceae. Microbial Pathogenesis 1:43-49.

Van Dijk W C, Verbrugh H A, Van Erne-van der Tol M E, Peters R, Verhoef J 1981 Escherichia coli antibodies in opsonisation and protection against infection. Journal of Medical Microbiology 14:381-389.

Van Oss C J 1978 Phagocytosis as a surface phenomonen. Annual Reviews of Microbiology 32:19-39.

Welch W D, Martin W J, Stevens P, Young L S 1979 Relative opsonic and protective activities of antibodies against $\mathrm{K} 1$, $\mathrm{O}$ and lipid A antigens of Escherichia coli. Scandinavian Journal of Infectious Diseases 11:291-301.

Wicken A J, Knox K W 1980 Bacterial cell surface amphiphiles. Biochimica et Biophysica Acta 604:1-26.

Williams P 1987 Sub-inhibitory concentrations of cefuroxime and ciprofloxacin influence interaction of complement and immunoglobulins with Klebsiella pneumoniae. Antimicrobial Agents and Chemotherapy 31 : 758-762.

Williams P, Lambert P A, Brown M R W, Jones R J 1983 Role of the $\mathrm{O}$ and $\mathrm{K}$ antigens in determining the resistance of Klebsiella aerogenes to serum killing and phagocytosis. Journal of General Microbiology 129:2181-2191.

Williams P, Lambert P A, Haigh C G, Brown M R W 1986 The influence of the $\mathrm{O}$ and $\mathrm{K}$ antigens of Klebsiella aerogenes on surface hydrophobicity and susceptibility to phagocytosis and antimicrobial agents. Journal of Medical Microbiology 21 : 125-132.

Williams P, Brown M R W, Lámbert P A 1984 Effect of iron deprivation on the production of siderophores and outer membrane proteins in Klebsiella aerogenes. Journal of General Microbiology 130 : 2357-2365.

Wolberg G, DeWitt C W 1969 Mouse virulence of K(L) antigen containing strains of Escherichia coli. Journal of Bacteriology 100: 730-737. 